\title{
II. Meşrutiyet Dönemi İslamcı Çizgideki Süreli Yayınlarda Aile ve Çocuk Eğitimi*
}

\section{Şeref Göküs ${ }^{* *}$}

Atıf/@: Göküş, Şeref, “II. Meşrutiyet Dönemi İslamcı Çizgideki Süreli Yayınlarda Aile ve Çocuk Eğitimi", Artuklu Akademi 2020/ 7 (1), 99-124.

Öz: Bu çalışmanın amacı; II. Meşrutiyet Dönemi matbuatında yer alan İslamcı çizgideki süreli yayın organlarında aile ve çocuk eğitiminin nasıl ele alındığını tespit etmektir. Söz konusu amaç doğrultusunda öncelikle araştırma konusuna ait ilgili literatür taranmış; aile ve çocuk eğitimi hususunda İslamcılık akımının görüşlerini yansıtan süreli yayınların isimleri belirlenmiştir. Betimsel tarama modeline göre hazırlanan bu çalışma neticesinde şu sonuçlara ulaşılmıştır: İslamcılar; ideal bir Osmanlı toplumu inşa etmede İslami usullere göre evlenip aile kurmayı ve oluşturulan bu aile ortamında çocuklara doğru ve tutarlı bir din ve ahlak eğitimi verilmesini devletin ve milletin varlığını sürdürmesine etki eden bir beka meselesi olarak görürler. Bu nedenle evlenecek olan kadın ve erkeğin İslamî literatürde sözü edilen maddi ve manevi özelliklere haiz olması gerektiği kanaatini taşırlar. Bununla birlikte İslamclar, Osmanlı ailesinin teşekkülünde Batı aile tarzının taklit edilmesine şiddetle karşı çıkarlar ve aile ortamında kadın ve erkeğe düşen görevlerin net bir şekilde belirlenmesi gerektiğini ifade ederler.

Anahtar Kelimeler: II. Meşrutiyet Dönemi, İslamcılar, aile ve çocuk eğitimi, din ve ahlak eğitimi, evlilik.

\section{Family and Child Education in the Islamist Viewpoint- Periodicals of the Second Constitutional Period}

Citation/@: Göküş, Şeref, "Family and Child Education in the Islamist Viewpoint- Periodicals of the Second Constitutional Period", Artuklu Akademi 2020/ 7 (1), 99-124. Abstract: The purpose of this study is to determine how family and child
education is discussed in the periodicals having Islamic viewpoint in the $2^{\text {nd }}$
constitutional period. To attain this goal, the relevant literature on the subject of

\footnotetext{
* Bu makale; 14-16 Kasım 2014 tarihinde İzmir'de düzenlenen “21. Yüzyılda Aile Sempozyumu”nda sunulan "II. Meşrutiyet Dönemi Süreli Yayınlarında Aile ve Çocuk Eğitimi" başlıklı bildiri metninin içerik ve kaynak açısından tekrar gözden geçirilip genişletilmiş halidir.

* Dr. Öğr. Üyesi, Akdeniz Üniversitesi İlahiyat Fakültesi Din Eğitimi Anabilim Dalı, serefgokus@akdeniz.edu.tr.
} 
the research was reviewed; the names of periodicals that reflect the views of the Islamist movement on family and child education were identified. As a result of this study, prepared in line with survey method, the following results were reached: While building an ideal Ottoman society, Islamists consider marriage and starting a family according to Islamic methods and providing a proper and consistent education of religion and morality to children in this family environment as a survival element that affects the existence of the state and the nation. For this reason, they believe that the man and women who will marry should possess the material and moral characteristics mentioned in the Islamic literature. Besides, Islamists strongly oppose to the imitation of the Western family-style in the formation of the Ottoman family and state that the duties of men and women should be clearly determined in family environment.

Keywords: II. Constitutional Period, Islamists, family and child education, religion and moral, marriage.

\section{Giriş}

II. Meşrutiyet, Osmanlı devletinde on yedinci yüzyıldan itibaren başlayan dinî, ahlakî, siyasi, sosyal, kültürel ve ekonomik bunalımların her yönünün yoğun bir biçimde tartışıldığı ve neticeye bağlayabilmek için üst düzey gayret sarf edildiği müstesna bir dönemdir. Bir bakıma 100 imparatorluğun sonuna doğru biriken sorunlar 1908'den sonra ayyuka çıkmış, toplumu ilgilendiren bu konuların bütünü dönemin aydınları tarafından enine boyuna incelenmiş ve tartışılmıştır. Kaosun şiddetlendiği ve sorunların çözülmesi için yapılan çalışmaların zirveye ulaştığı II. Meşrutiyet dönemi, bu yönüyle kendisinden sonraki zaman dilimlerini de etkileyen bir yapıya sahiptir. Kanaatimizce böyle bir etkinin en önemli sebeplerinden birisi bu süreçte yayın hayatına atılan dergi ve gazete sayısındaki ciddi artış ve bu süreli yayınların faaliyetlerine bağlı olarak oluşan toplumsal kamuoyudur. Dönemin aydınlarının mensubu oldukları süreli yayınlarda dile getirdiği “ bu devlet nasıl kurtulmalıdır?" sorusu neticesinde oluşan söz konusu toplumsal kamuoyu, Osmanlı toplumundaki eğitim, aile, din, maliye, hukuk, ahlak ve siyaset gibi insanlar üzerinde hem bireysel hem de toplumsal anlamda önemli bir etkiye sahip olan bu meselelerin aksayan yönlerinde acilen sslahat yapılması noktasında hemfikirdirler. ${ }^{1}$

$\mathrm{Bu}$ çerçevede sayıları yüzleri bulan süreli yayınlarda ${ }^{2}$ toplumsal problemlerin tespit edilmesine yönelik birbirinden farklı birçok makale

Geniş bilgi için bkz. Şeref Göküş, “II. Meşrutiyet Dönemi Türkçülük Akımında Eğitim, Din Eğitim ve Öğretimi", (Yayımlanmamış Doktora Tezi, Ankara Üniv. Sosyal Bilimler Enstitüsü, Ankara 2013): VII-12.

2 Süreli yayınlarla ilgili geniş bilgi için bkz. Bülent Varlık, "Tanzimat ve Meşrutiyet Dergileri", Tanzimat'tan Cumhuriyet'e Türkiye Ansiklopedisi, C.1, (İstanbul: İletişim Yayınları, 1985); Zafer Toprak, “II. Meşrutiyet'te 
kaleme alınmıştır. Dönemin karakteristik özelliğine baktığımızda söz konusu süreli yayınlarda, köşe yazarlığı yapan aydınların genel olarak üç farklı düşünce akımına mensup olduğunu görüyoruz. Bu düşünce akımları Batıcılık, İslamcılık ve Türkçülüktür. II. Meşrutiyet Dönemi'nde yaşanan sorunların tespit edilmesi, halka duyurulması ve neticesinde bir tartışma ortamının hazırlanması konusunda, söz konusu aydınlar, üzerlerine düşen görevleri eksiksiz bir şekilde yerine getirmeye gayret etmişlerdir. Bu süreçte ilgili aydınların köşe yazarlığı yaptıkları gazete ve dergilerde devamlı Osmanlı'nın geri kaldığı alanlara vurgu yapmaları, bu meselede, yeni bir merhalenin ortaya çıkmasına neden olmuştur. Şöyle ki; ortaya konan bu sorunların çözümündeki temel hareket noktası ne olmalıdır? Bu hareket noktası hangi fikrî ya da felsefî düşünce üzerine inşa edilmelidir? Tabi böyle soruların sıkça dile getirilmesiyle birlikte süreli yayınlardaki yazıların başlığı ve içeriği de bu amaca uygun olarak değişmeye başlamıştır. Bu şekil ve muhteva değişikliğinde, toplumsal sorunların tespit edilmesindeki birliktelik yerini yavaş yavaş görüş ayrılıklarına ve bazı fikrî tartışmalara bırakmıştır. Öyle ki bu süreçte Batıcılar, İslamcılar ve Türkçüler kendi görüşlerini bir diğerinin ortaya koyduğu çözüm önerisine göre belirlemeye ve adeta bir savunma psikolojisi içerisine girmeye başlamışlardır.

Buna göre Batıcılar; eğitim, aile, din, maliye, hukuk, ahlak ve siyaset gibi konulara ait sorunların çözümünün ancak gelişmiş Avrupa toplumlarının yakinen tanınması ve onların birçok açıdan taklit edilmesi sayesinde gerçekleşebileceğini iddia ederler. ${ }^{3}$ İslamcılar ise Batıcıların bu düşüncesine karşı çıkarak bir Müslümanın başvuracağı başlıca referans kaynağının ancak İslamiyet ve buna bağlı olarak şekillenen dinî ve ahlakî öğretiler olması gerektiğini dile getirirler. ${ }^{4}$ Türkçüler ise toplumsal problemlerin çözümünde manevi değerler yanında insanlar arasındaki birlik ve beraberliği arttıran millî unsurlara da önem verilmesi gerektiğini ifade

Fikir Dergileri”, Tanzimat'tan Cumhuriyet'e Türkiye Ansiklopedisi, C.1, (İstanbul: İletişim Yayınları, 1985); Ülkü Gürsoy, "II. Meşrutiyet Dönemi Dergileri Üzerine Bir Araştırma”, (Yayımlanmamış Doktora Tezi, Gazi Üniv. Sosyal Bilimler Enstitüsü, Ankara 1991).

3 Batıcılık akımıyla ilgili geniş bilgi için bkz. Tarık Zafer Tunaya, Türkiyénin Siyasi Hayatında Batılılaşma Hareketleri, (İstanbul: İBÜY, 2004); Şükrü Hanioğlu, "Batıcılık", Tanzimat'tan Cumhuriyet'e Türkiye Ansiklopedisi, C.5, (İstanbul: İletişim Yayınları, 1985); Recai Doğan, "II. Meşrutiyet Döneminde Batıcllık Akımının Din ve Eğitim-Öğretim Görüşlerinin Değerlendirilmesi”, (Yayımlanmamış Doktora Tezi, Ankara Üniv. Sosyal Bilimler Enstitüsü, Ankara 1996).

4 İslamcılık akımıyla ilgili geniş bilgi için bkz. Tarık Zafer Tunaya, İslamcılık Akımı, (İstanbul: İBÜY, 2003); İsmail Kara, “Tanzimat'tan Cumhuriyet'e İslamcılık Tartışmaları", Tanzimat'tan Cumhuriyet'e Türkiye Ansiklopedisi, C.5, (İstanbul: İletişim Yayınları, 1985); Recai Doğan, İslamcıların Eğitim ve Öğretim Görüşleri, (Ankara, 1999); Muhammet Şevki Aydın, İslâmcıların Din Eğitimine Bakışı: Mehmed Şemseddin Günaltay Örneği, (Ankara: Sarkaç Yayınları, 2013). 
ederler. ${ }^{5}$ Aslında, ilgili literatüre bakılırsa, ${ }^{6}$ bu üç fikir akımına mensup aydınların dönemin mevcut sorunlarını tespit ederek onları bertaraf etmeleri neticesinde ulaşmak istedikleri temel amaç; Osmanlı İmparatorluğu'nun içinde bulunduğu sıkıntılı durumdan kurtulması ve eski ihtişamlı günlerine tekrar kavuşmasıdır. Görüldüğü üzere amaç aynıdır; ancak sözü edilen hedefe ulaşmak için fiiliyatta tutulan yollar ise birbirinden farklıdır. Bu bağlamda söz konusu fikrî tartışmalar içerisinden müstakil olarak İslamcıların aile ve çocuk eğitimi ile ilgili görüşleri çalışmamızın ana konusunu oluşturmaktadır.

\section{Araştırmanın Amaç ve Yöntemi}

\section{A. Araştırmanın Amacı}

II. Meşrutiyet Dönemi ile birlikte basın hayatında adeta bir patlama yaşanmış, her alanda farklı, zengin ve bol renkli bir matbuat dünyası ortaya çıkmıştır. Bu dönem, her türlü fikir ve düşüncenin ileri sürülüp tartışıldığı ve süreli yayınlar yoluyla halka duyurulduğu bir dönemdir. Bu bağlamda II.

102 Meşrutiyet Dönemi'nin dikkate alınmasının "ardında duran somut gerçekliklerin başında basın, siyaset ve sosyal hayatta yaşanan ilkler ve dönüşümlerin" olduğunu belirtmek gerekir. ${ }^{7}$

II. Meşrutiyet ile toplum yaşantısında meydana gelen hızlı değişim ve dönüşümün etkisi ailede de kendini göstermiştir. Geleneksel eğitim yerine Batı tarzı eğitim modelinin benimsenmesi, bu tarz okulların yaygınlık kazanması, aile yapısının ve çocuk eğitiminin nasıl olması gerektiği konusunda farklı fikirlerin ortaya çıkmasını sağlamıştır. Bu süreçte aile ve çocuk eğitiminin içeriğine ve nasıl yapılması gerektiğine yönelik bazı hususlar Batıcılar, İslamcılar ve Türkçüler tarafından farklı minvalde ele alınmıştır.

Bu çalışmada; II. Meşrutiyet Dönemi matbuatında yer alan İslamcı çizgideki süreli yayın organlarında aile ve çocuk eğitiminin nasıl ele alındığı belirlenmeye çalışılacaktır. Buradan hareketle, İslamcıların aile kurup çocuk yetiştirmede, çocuklara verilmesi gereken din ve ahlak eğitiminde hangi

Türkçülük akımıyla ilgili geniş bilgi için bkz. Ali Engin Oba, Türk Milliyetçiliğinin Doğuşu, (Ankara: İmge Yayıncılık, 1995); Yusuf Sarınay, Türk Milliyetçiliğinin Tarihi Gelişimi ve Türk Ocakları, (İstanbul: Ötüken Yayınları, 2004); Mehmet Karakaş, Türk Ulusçuluğunun İnşası, (Ankara: Vadi Yayınları, 2000).

6 Örneğin bkz. Mustafa Gündüz, "II. Meşrutiyet Dönemi Türkçü, İslâmcı ve Batıcı Görüşlere Mensup Aydınların Toplumsal Değişme Telakkîleri”, Muhafazakâr Düşünce, I/4, (2005); 95-122.

7 Mustafa Gündüz, “100. Yılında II. Meşrutiyet'in Kültürel Mirası”, Milli Eğitim, 184, (2009), 122. 
esaslar üzerinde durdukları ve bu süreçte nelere dikkat ettikleri araştırılacaktır. Bu sayede İslamcıların, hem aile ve çocuk eğitimi hakkında Batıcı ve Türkçü aydınlardan farklı düşündüğü noktaların tespit edilip karşılaştırılmasına hem de o dönemden günümüze kadar cereyan eden evlenmek ve aile kurmak, kadın ve erkeğin ailedeki konumu, aile bireylerinin görev taksimi, ailede çocuklara nasıl bir din ve ahlak eğitimi verilmesi gerektiği gibi tartışmaların daha iyi anlaşılmasına ve meselenin asıl çıkış noktasına inilmesine katkı sağlanacağı da düşünülmektedir.

\section{B. Araştırmanın Yöntemi}

Araştırma, tarama modelinde betimsel bir çalışmadır. Bu çalışma ile İslamcıların aile kurup çocuk yetiştirmede, çocuklara verilmesi gereken din ve ahlak eğitiminde hangi esaslar üzerinde durduklarını ve bu süreçte nelere dikkat ettiklerini analiz etmek hedeflendiği için betimsel tarama modeli kullanılmıştır. Zira tarama modelleri, "geçmişte ya da halen var olan bir durumu var olduğu şekliyle tespit edip" betimlemeyi amaç edinen araştırmalar için uygun olan bir modeldir. ${ }^{8}$

Verilerin toplanmasında belgesel tarama tekniği kullanılmıştır. Belgesel tarama, "var olan kayıt ve belgelerden veri toplama tekniğidir." ${ }^{9} \mathrm{Bu}$ bağlamda öncelikle ilgili literatür taranmış ${ }^{10}$ ve İslamcı çizgideki süreli yayınların isimlerinin Beyanü'l-Hak, Ceride-i Ilmiye, Ceride-i Sufiye, Cihan-ı İslam, el-İslam, el-Medaris, el-Mirsad, Hayrü'l-Kelam, Hikmet, İş̧adü'l-Müslimin, İslam Dünyası, İslam ve Ulum, I'tisam, İttihad-ı İslam, Kelime-i Tayyibe, Maşrık-i Irfan, Medrese Itikadları, Mikyas-ı Şeriat, Muhibban, Rehber-i Vatan Sada-i Hak, Sebilürreşad, Sırat-ı Müstakim, Tasavvuf, Tearüf-i Müslimin ve Volkan olduğu tespit edilmiştir. Akabinde, Milli Kütüphane, Hakkı Tarık Us kütüphanesi ve İstanbul Büyükşehir Belediyesi Atatürk Kitaplığı ile İslamcı Dergiler Projesi arşivlerinde yer alan süreli yayın kataloglarından ilgili dergilere ulaşılmıştır. $\mathrm{Bu}$ süreçte izdivaç/evlenme, aile, kadın, çocuk, din, ahlak, terbiye/eğitim, ta'lim/öğretim gibi kavramlar belirlenmiş ve adı geçen dergilerin tüm sayıları, söz konusu kavramlar dikkate alınarak, teker teker taranmıştır. Yapılan

\footnotetext{
Niyazi Karasar, Bilimsel İrade Algı Çerçevesi ile Bilimsel Araştırma Yöntemi: Kavramlar-Illkeler-Teknikler, 35. Bsk., (Ankara: Nobel Yayın Dağıtım, 2016), 108.

9 Karasar, Bilimsel İrade Algı Çerçevesi ile Bilimsel Araştırma Yöntemi: Kavramlar-İlkeler-Teknikler, 229.

10 Mustafa Gündüz, II. Meşrutiyet'in Klasik Paradigmalar, (Ankara: Lotus Yayınevi, 2007), 21-63; Gürsoy, "II. Meşrutiyet Dönemi Dergileri Üzerine Bir Araştırma", 1-65; Varlık, "Tanzimat ve Meşrutiyet Dergileri", 116125; Toprak, "II. Meşrutiyet'te Fikir Dergileri", 126-132.
} 
işlemler neticesinde ortaya çıkarılan veriler, bilgisayar aracılığıyla fişlenerek kayıt altına alınmıştır.

Verilerin analizinde ise betimsel analiz yöntemi tercih edilmiştir. Betimsel analiz, farklı veri toplama teknikleri sayesinde ortaya çıkarılan "verilerin daha önceden belirlenmiş temalara göre özetlenmesi ve yorumlanmasını" kapsayan nitel bir analiz çeşididir. Bu bağlamda araştırmada; belgesel tarama tekniği ile elde edilen ve bilgisayar aracilığıyla fişlenen veriler tekrar gözden geçirilmiş; ilgili verilerin "evlenip aile kurmak" ve "ailede çocuk eğitimi" temaları altında anlamlı ve mantıklı bir şekilde, gerektiğinde doğrudan alıntılardan da faydalanılarak, ele alınıp düzenlenmesine ve yorumlanarak sunulmasına karar verilmiştir. ${ }^{11}$

\section{II. İkinci Meşrutiyet Dönemi İslamcı Çizgideki Süreli Yayınlarda Aile ve Çocuk Eğitimi}

\section{A. Evlenip Aile Kurmak}

İslamcılar evlenip aile kurmayı Osmanlı toplumunun bugününü ve geleceğini inşa etmedeki en önemli meselelerden biri olarak görürler. Zira onlara göre aile, toplumun en küçük yapı taşıdır. Aileler bir araya gelerek toplumu oluşturduğuna göre, bu yapının sağlam temeller üzerine bina edilmesi demek aynı zamanda o ailenin içerisinde bulunduğu toplumun da aynı derecede sağlam bir hüviyete ve bünyeye sahip olması anlamına gelmektedir. Bir başka ifade ile İslamcılar; "milletlerin ictimai tekâmülleri, iktisadi mevkileri, siyasi satvetleri o milletleri teşkil eden ailelerin refah ve saadetleri, ahenk ve seciyeleriyle kaimdir" diyerek aile kurmayı ve kurulan ailedeki ahengi, düzeni, huzur ve mutluluğu; toplumun ictimai, iktisadi ve siyasi gelişmişliğine doğrudan etki eden temel dinamiklerinden biri olarak kabul ederler. ${ }^{12}$

Konunun önemine binaen İslamcıların Osmanlı aile hayatını ele alan yazılarında üzerinde durdukları ilk hususlardan biri izdivaç meselesidir. Onlara göre evlenmek yüce Allah'ın bir emri, Hz. Peygamberin ise bir sünnetidir. Bu emir İslamî olduğu kadar aynı zamanda insanî ve ahlakî bir emirdir. Evlilik insanoğlunun fıtratının bir gereğidir. Yoksa bu faaliyet bir

Ali Yıldırım \& Hasan Şimşek, Sosyal Bilimlerde Nitel Araştırma Yöntemleri, 9. Bsk., (Ankara: Seçkin Yayınları, 2013): 256-258.

12 M. Şemseddin, "İctimaî Derdlerimizden İzdivac Mesele-i Mühimmesi”, Kelime-i Tayyibe, 1/11, (27 Eylül 1328): 341. Ayrıca bkz. İbnü'l-Emin Ahmed Tevfik, "Esas Terbiye”, Beyanü'l-Hak, 1/20, (2 Şubat 1324): 453. 
zorlama veyahut angarya olarak kabul edilmemelidir. Nitekim İslam dininin hem Kur'an'da hem de hadislerde evlenmeyle ilgili vurgulamak istediği husus bu fitrî ve insanî yöndür. Buradaki fitrî ve insanî yönden kasıt ise insanları bilinçlendirmek ve kendileri için daha güzel ve daha hayırlı olan bu yöne teşvik etmektir. Bu noktada İslamcılar konuyla ilgili Kur'an-1 Kerim'den "Ve içinizden bekâr olanları ve kadın ya da erkek kölelerinizden (evlenmesi) uygun olacak olanları evlendirin. (Evlenmeye niyeti olanlar) yoksul iseler, (bu sizi kaygilandırmasın), Allah onları lütfuyla destekleyecektir..." ${ }^{13}$ gibi ayetler ve Hz. Peygamberden "Nikâh benim sünnetimdir. Kim bu sünnetimden yüz çevirirse benden değildir." 14 gibi hadisler zikrederek evlilikle ilgili görüşlerini delillendirmeye çalışırlar. ${ }^{15}$

İslamcılar, bununla birlikte, evlenip aile kurmayı bir ibadet olarak da kabul ederler. Bu nedenle izdivaç yapmak isteyen kadın ve erkeğin evliliğe hazırlanmasını, bedenen ve ruhen bu önemli sorumluluğu kaldıracak bir meziyete sahip olmasını isterler. Onlar aynı zamanda bu ibadetin yani izdivacın usulüne göre ifa edilmesi taraftarıdırlar. Bu bağlamda karı koca arasındaki evlilik bağının belirli prensipler üzerine inşa edilmesini talep eden İslamcılar; "Hülasa taleb-i tezevvüc olan bir adamın evvela tezevvüce talip olduğu kız veya kadına kifâyeti, mehir, nafaka, süknaya, teşkil-i aileye, hukuk-1 zevciyeti tamamiyla ifaya kudreti tahakkuk etmeli... Bunlar tahakkuk ederse evlenmeli. Tahakkuk etmediği halde teehhülden sarf-1 nazar edip emr-i tezevvücün tavakkuf ettiği şeyleri tahsil edecek ve şeraitini ikmal eyleyecek esbaba tevessül eylemeli. Ba'dehu yine küfüvvü olduğu bir kız veya kadınla tezevvüc etmeli." diyerek evlenmek isteyen tarafların bu görevi gerçekleştirecek bir yeterliliğe ve yetkinliğe haiz olması gerektiğine dikkat çekerler. ${ }^{16}$ Aynı şekilde İslamcılar: "Aile teşkil etmek, evlat ve iyâlinin istirahatlerini temin ve kendilerini talim ve terbiye ile tezyin eylemek, devlete ve millete hizmet edecek bir hale getirmek ancak para ile mümkün olabilir" diyerek evlenmeden önce kişinin bu fiili yerine getirecek ve hatta evlilik sonrası bu görevini devam ettirecek kadar maddi imkânlara sahip olması gerektiğinden de söz ederler. İslamcılara göre ebeveynlerin en önemli vazifelerinden biri çocuklarının geçimini sağlamak ve en güzel imkânları sunarak onları hayata hazırlamaktır. Bu amaçla İslamcılar; hem kişilerin gerektiği kadar helal olan işlerde çalışmasını ve para kazanıp ailesine

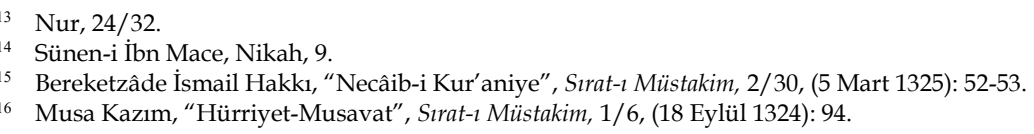


bakmasını tavsiye ederler hem de bu fiili Allah'ın övdüğü, insanların ise bireysel olarak değer verip takdir ettiği ahlaki bir davranış olarak kabul ederler. $^{17}$

İslamcılara göre izdivaç yapmak isteyen bireylerde bulunması gereken söz konusu hasletler yanında dikkat edilmesi gereken bir diğer önemli nokta ise evlilik öncesinde erkek ve kadın arasında "bir alakanın, bir münasebet-i kimyeviyenin" 18 oluşması ve iki tarafın da karşılıklı olarak "yekdiğerini beğenmesi" gerektiğidir. ${ }^{19}$ Bir kimyager nasıl ki ilaç yapımında değişik maddeleri birbirine karıştırıp onları uyumlu hale getiriyorsa, evlilik işiyle uğraşan kimseler de aynen onun gibi davranmalı; kadın ve erkeğin anlaşıp anlaşamadığına, birbirlerine karşı kalplerinin ısınıp ısınmadığına dikkat etmelidir. Bu süreçte aileler çocuklarına yardım etmeli; lâdînî örfler, adetler, gelenek ve göreneklere bağlı olarak oluşan çevre baskısına karşı dirayetli bir tutum sergileyerek evliliklerin mutluluk yerine adeta bir külfete dönüşmesine engel olmalıdır. Sırf itibarı ve parası var diye genç kızlar kendilerinden daha yaşlı ihtiyarlarla evlendirilmemelidir. Evlilik sürecinde kesinlikle İslam'ın emrettiği çerçeveler içerisinde hareket edilmeli, gençlerle daima istişare içinde olunarak onlara evliliğin amacı ile önemi anlatılıp daha bilinçli bir şekilde izdivaç yapmalarına katkı sağlanmaya çalışılmalıdır. ${ }^{20}$

Evlenip aile kurmanın şartlarını bu şekilde ortaya koyan İslamcılar, bunun yanında, izdivaç yapmanın kadın ve erkeğe sağladığı faydaların neler olduğuna da dikkat çekerler. Buna göre evlilik; 1-kadın ve erkeğin karşılıklı olarak iffetlerini koruma altına almasını, 2-insan neslinin çoğalması ve devamının sağlanmasını, 3-erkeğin ve kadının dünya ve ahiret saadetine yönelik faaliyetlerdeki azminin ve isteğinin artmasını sağlayan önemli bir bağdır. İslamcılar, kadın ve erkek arasında var olmasını istedikleri bu bağın oluşması için onların mutlaka birbirleri ile nikâhlanması gerektiğine inanırlar.

17 Mehmed Esad, “İnsanın Mahiyeti ve Vazaif-i Şeri'ye ve İctimaiyesi”, Sırat-ı Müstakim, 1/12, (30 Teşrin-i Evvel 1324): 190.

18 Şemseddin, "İctimaî Derdlerimizden İzdivac Mesele-i Mühimmesi", 343.

19 Kazım, "Hürriyet-Musavat", (18 Eylül 1324): 94.

20 Şemseddin, "İctimaî Derdlerimizden İzdivac Mesele-i Mühimmesi", 342-343. İslamcıların evliliğin önemi hakkındaki bu görüşlerine ilaveten dönemin Sırat-ı Müstakim dergisinde Şeyhülislamlık makamının Dâhiliye Nezareti'ne gönderdiği bir yazıdan bahsedilerek onların oluşturmaya çalıştıkları bu ahlaki bilince bir katkı sağlamanın amaçlandığını görüyoruz. Şeyhülislamlık makamı söz konusu yazısında evlenmek ve bir yuva kurmak isteyen kadın ve erkeğin bu isteklerinin gerçekleşmesine mâni olan gayr-i dînî uygulamaların neler olduğunun tespit edilerek bu hususların bir an evvel ortadan kaldırılması konusunda gerekli çalışmaların yapılmasını istemektedir. İslamcılar, Şeyhülislamlık tarafından hurafe bidatlere karşı takınılan bu tavır ile onun uygulama boyutundaki kontrollerin evlilik kurumunun gelişmesi ve güvence altına alınmasında dikkate değer bir katkıya sahip olduğunu belirtmektedir. Bu bilgi için bkz. "Teshil-i İzdivac Hakkında", Sırat-ı Müstakim, 4/88, (29 Nisan 1326): 178. 
Nikâhsız bir birlikteliği kesin bir dille reddederler. Onlara göre evlenmeyle insanlar çoğalır ve böylece Müslüman toplumunun geleceği güvence altına alınır. Bu sadece Müslümanlar için değil; aynı zamanda bütün dünyanın varlığı ve bekası için gerekli bir faaliyettir. Evlenmek, insanların dünya ve ahiret hayatını etkileyen önemli bir ibadettir. Öyle ki insanlar evlilik sayesinde birbirlerine bağlanır, birbirlerine güvenir ve birbirlerine karşı sevgi ve saygı duymayı öğrenir. Böylesi bir durum ise erkek ve kadının hem bireysel hem de toplumsal hayatında daha mutlu ve daha huzurlu bir yaşam sürmesine sebep olur. ${ }^{21}$ Yoksa İslamcılar, evlenmenin yalnızca dünyevi arzulara/isteklere ulaşmak ya da sadece çocuk sahibi olmak gibi amaçlarla yapılmasını doğru bulmazlar ve böylesi bir anlayışa net bir dille karşı çıkarlar. Aksine onlara göre evlilikte göz önüne alınması gereken en temel husus Allah'ın rızasını kazanmak/gözetmek olmalıdır. Zira izdivaçla ilgili sadece dünyevi hedefleri olan kimseler bunları elde ettiği zaman belki de evlilikten ve evli olmanın verdiği sıkıntılardan bunalıp yuvasını dağıtabilecekken; buna karşılık Allah’ın rızasını gözeten kişiler ise evliliği boyunca karşılaştı̆̆ı problemlere karşı daha metanetli bir duruş sergileyerek başına gelenlerin bir imtihan olduğunu düşünüp evliliğini devam ettirmenin yollarını/çarelerini arayabilirler. $^{22}$

Osmanlı toplumunun bekası için evlilik kurumunun bozulmadan eski hüviyetini koruması gerektiğine inanan İslamcılar, bu konuda, Avrupa toplumlarındaki bazı yanlış uygulamalardan örnekler vererek dönemin Müslüman Türk toplumunu bu yozlaşmaya karşı uyarmaya çalışırlar. Onlara göre Batı' da ekonomik bağımsızlığını elde eden kadın ve erkeğin evlenmek yerine başka arayışların içerisine girmesi ve adeta evlenmeyi hoş olmayan ya da tercih edilmeyen bir faaliyetmiş gibi göstermeye çalışması doğru bir bakış açısı değildir. Orada moda denilerek başkasını taklit etmeye çalışıp bir giydiğini bir daha giymemek ve zengin bir hayat sürmek maksadiyla kaldıramayacağı borçların altına girip ekonomik anlamda sıkıntı çekmek gibi bazı istenmeyen menfi faaliyetler, gençlerin bireyselleşmesine ve buna bağlı olarak onların aile kurmasına engel olmaktadır. İslamcılar açısından, gençler arasında evliliğe yönelik var olan bu olumsuz bakış açısı önemli bir problemdir ve bu problemin Osmanlı toplumuna sirayet etmesi ise oldukça

\footnotetext{
1 Musa Kazım, "Hürriyet-Musavat", Strat-ı Müstakim, 1/4, (4 Eylül 1324): 54; Musa Kazım, "HürriyetMusavat", Sırat-ı Müstakim, 1/5, (11 Eylül 1324): 68-70; İskilipli Mehmed Atıf, "Medeniyet-i Şer'iye, Terakkiyat-1 Diniye (Vazâif-i Zevce), Beyanü'l-Hak, 7/169, (16 Temmuz 1328): 2971-2972.

22 "İslam ve Kadınlar: Mazi, Hal ve İstikbal", Hikmet, 14, (8 Temmuz 1326): 5.
} 
tehlikelidir. ${ }^{23}$ Zira evlilik müessesinin bozulması o toplumdaki dinî, ahlakî ve insanî meziyetlerin gerilemesi anlamına gelmektedir ki İslamcılar ulaşmak istedikleri "İttihad-1 İslam" idealine engel olabilecek böyle olumsuz bir durumla karşılaşmaya şiddetle karşı çıkarlar. Bunun yanında bekâr iken nikâhsız bir şekilde herhangi bir erkekle uygunsuz hal ve tavırların içerisine giren kadınların, söz konusu fiillerinin, evlendikten sonra duyulması ihtimalinin sonuçlarından da bahseden İslamcılar, bu ve benzeri örneklerle özellikle kadınlara yönelik ahlakî bir bilinç oluşturmaya gayret ederler. ${ }^{24}$ Fakat aynı ahlakî bilinç konusunda nedense erkeklerin vazifelerinden hiç söz etmezler. Aynı şekilde benzer olumsuz fiiller karşısında toplumun erkeğe yönelik bakış açısının nasıl olduğu ya da nasıl olması gerektiği hakkında da yine herhangi bir görüş belirtmezler.

İslamcılar, kadın ve erkeğin evlilikleri boyunca hangi görevleri üstlenmesi gerektiğini kendi cinsiyetleri bağlamında ele almaya çalışırlar. Onlara göre Allah insanları fıtratları gereği birbirinden farklı bir şekilde yaratmıştır. Bu sebeple erkeklerde bulunan bedenî ve ruhî hasletlerin bazıları kadınlarda, kadınlarda bulunan bedenî ve ruhî meziyetlerin bazıları ise erkeklerde olmayabilir. Örneğin kadınlar narindir, naziktir, hassastır; erkekler ise daha metindir ve fiziki olarak daha kuvvetlidir. Ancak söz konusu farklılıklar asla birinin yekdiğerini dışlamasına ya da onu küçük görüp aşağılamasına yol açmamalıdır. Aksine kadın ve erkeği birbirine bağlayan temel etkenlerden biri, belki de her iki cinsteki bu benzerlikler ve tezatlıklardır. ${ }^{25}$ İslamcılar bu gerçeklerden hareketle evde yapılması gereken işleri ev içi ve ev dışı olmak üzere ikiye ayırırlar. Evin dışındaki işlerle ilgili görevleri erkeklerin, evin içindeki işlerle ilgili vazifeleri ise kadınların yerine getirmesini isterler. Buna göre erkeklere karısının ve çocuklarının iaşesini sağlama, onların barınma ve korunma gibi ihtiyaçlarını giderme, resmî ve

23 Ahmed Şevki, "Müslümanlarda Aile Hayatı”, Beyanü'1-Hak, 3/71, (19 Temmuz 1326): 1392-1393; Ahmed Şevki, "Müslümanlarda Aile Hayatı", Beyanü'l-Hak, 3/72, (26 Temmuz 1326): 1407-1408; Ahmed Şevki, “Müslümanlarda Aile Hayatı”, Beyanü'l-Hak, 3/78, (6 Eylül 1326): 1502-1504; Ferid Vecdi, “Müslüman Kadını (Dördüncü Faslın Maba'dı)", Sırat-1 Müstakim, Müt: Mehmed Akif, 1/7, (25 Eylül 1324): 106-107; Şemseddin, “İctimaî Derdlerimizden İzdivac Mesele-i Mühimmesi”, 344-345.

24 Ferid Vecdi, "Müslüman Kadını (Beşinci Fasıl: Kadın A'mal-i Hariciyede Erkekle Müşareket Edebilir Mi?)”, Sırat-ı Müstakim, Müt: Mehmed Akif, 1/8, (2 Teşrin-i Evvel 1324): 123-124; Ahmed Şevki, "Müslümanlarda Aile Hayatı", Beyanü'l-Hak, 4/79, (13 Eylül 1326): 1523-1525.

25 Ferid Vecdi, "Müslüman Kadını (Birinci Fasıl: Kadın Nedir?)”, Strat-ı Müstakim, Müt: Mehmed Akif, 1/4, (4 Eylül 1324): 57; Ferid Vecdi, "Müslüman Kadını (Üçüncü Fasıl: Kadın Bedenen ve Ruhen Erkekle Bir Olabilir Mi?)", Strat-ı Müstakim, Müt: Mehmed Akif, 1/4, (11 Eylül 1324): 76-78; Ferid Vecdi, "Müslüman Kadını (Dördüncü Fasıl)", Strat-ı Müstakim, Müt: Mehmed Akif, 1/6, (18 Eylül 1324): 90-91; Vecdi, “Müslüman Kadını (Dördüncü Faslın Maba'dı)”, 103-104; “İslam ve Kadınlar: Mazi, Hal ve İstikbal”, 4-5. 
gayr-i resmî işlemlerini takip etme gibi mesuliyetler verilirken; ${ }^{26}$ kadınlara ise ev işleriyle uğraşma, çocuk doğurup annelik yapma ve toplumun geleceğinin mimarları olan yavrularının dinî ve ahlakî meziyetlerinin oluşmasına katkı sağlama gibi sorumluluklar yüklenmiştir. Bununla birlikte İslamcılara göre kadınlar evdeki mesuliyetleri dışında topluma faydası olan zaruri işlerde çalışabilir, fakat bunlar asla onların aile içerisinde kendilerine verilen temel vazifelerini ihmal edip geçiştirmesi anlamına gelmemelidir. ${ }^{27}$

\section{B. Ailede Çocuk Eğitimi}

İslamcılar, çocukların bilinçli bir şekilde yetişmesinde ailedeki eğitimöğretim faaliyetlerinin önemli bir yeri olduğuna inanırlar. Onlara göre çocuklar Allah'ın doğuştan kendilerine verdiği fitrî özellikleri bünyelerinde barındırarak, her türlü kötülükten ve her türlü şer işlerden uzak, tamamen saf ve temiz bir şekilde dünyaya gelirler. Hz. Peygamberin hadisinde belirttiği gibi "Her çocuk fitrat üzere doğar. Sonra anne babası onu Hıristiyan, Yahudi veya Mecusi yapar." ${ }^{28}$ Dolayısıyla insanın doğuştan ahlaklı ya da ahlaksız olması gibi bir durum söz konusu değildir. Asıl mesele bu süreçten sonra başlamaktadır. Bu nedenle yüce yaratıcının insanoğluna bahşettiği bu melekelerin eğitim yoluyla kademeli bir şekilde ortaya çıkarılması gerekmektedir. İslamcılara göre bu ilk görev tabiî olarak aile ocağında gerçekleşmelidir. ${ }^{29}$ Aile ocağındaki terbiyeden gaye ise "çocuğun saadet ve

26 Ali Fuad, “Alem-i İslam' da Tesettür-i Nisvan ve Taaddüd-i Zevcat”, Ceride-i Sufiye, 1/6-8, (13 Kanun-i Sani 1327): 1; Mehmed Vefa, "Sefahat ve Kadınlarımı", el-Medaris, 11, (10 Temmuz 1329): 169-170; "İslam ve Kadınlar: Mazi, Hal ve İstikbal", 5.

27 İsmail Safayhi, "Kızlarımıza Ne Okutalım?", İslam Dünyası, 1/24, (1329): 388; Ferid Vecdi, "Müslüman Kadını (İkinci Fasıl: Kadının Vazife-i Tabiiyesi Nedir?)", Sırat-ı Müstakim, Müt: Mehmed Akif, 1/4, (4 Eylül 1324): 58-60; Ferid Vecdi, “Müslüman Kadını (Kadının Fıtratında Erkek İşlerine Girișebileceğini Gösterir Bir Şey Var mıdır?)”, Sırat-ı Müstakim, Müt: Mehmed Akif, 1/9, (9 Teşrin-i Evvel 1324): 139-141; Vecdi, "Müslüman Kadını (Dördüncü Faslın Maba'dı)", 104-105. İslamcılar erkeklerin ve kadınların ev içinde ve dışında hangi görevleri yüklenmesi gerektiği konusunda Batı toplumlarının örnek alınmasına karşı çıkarlar. Onlara göre Avrupa'da ailelerin oluşması, kendi içerisindeki görev taksimi, erkek ve kadınlara yüklenen sorumluluklar Türk toplumundan oldukça farklıdır. Çünkü her toplumun kendi bünyesine uygun bir hayat tarzı bulunmaktadır. Bu nedenle Batıdaki aileler hakkında bilgi sahibi olunabilir ancak her şeyiyle onların alınıp taklit edilmesi doğru değildir. İslamcılar, Batı́ daki ailelerin taklit edilmesine bahane olarak gösterilen Avrupalı kadınların Osmanlı kadınından daha üstün meziyetlere sahip olduğu kanaatini eleştirirler. Konuyla ilgili görüşlerini desteklemek içinse her iki toplumdaki kadınları; aile, çocuk eğitimi, fedakârlık, namus, iffet ve asalet gibi hasletler konusunda karşılaştırarak Osmanlı kadınının söz konusu hususlarda yaptıklarını Avrupalı kadınların yerine getirmesinin mümkün olmadığını dile getirirler. Geniş bilgi için bkz. Şevki, “Müslümanlarda Aile Hayatı”, (19 Temmuz 1326): 1392-1393; M. Safvet, "Şark ve Garp Kadınları", Beyanü'l-Hak, 3/74, (9 Ağustos 1326): 1437-1440; Musa Kazım, "Hürriyet-Musavat", Strat-l Müstakim, 1/7, (25 Eylül 1324): 99-101; Şemseddin, "İctimaî Derdlerimizden İzdivac Mesele-i Mühimmesi”, 344-345; Vecdi, "Müslüman Kadını (Dördüncü Fasıl)”, 91-93.

28 Sahih-i Buhari, Cenâiz, 92.

29 M. Şemseddin, "Nesl-i Atinin Talim ve Terbiyesi", Kelime-i Tayyibe, 1/6, (28 Haziran 1328): 178-179; Samizade Süreyya, “Terbiye-i Etfal”, Tearüf-i Müslimin, 1/24, (18 Teşrin-i Sani 1326): 386. 
refah-1 müstakbelesini temin etmek, onu mücadele-i hayata hazırlamak ve o mücadelede muzaffereyetine medar olacak esaslarla kendisini techiz etmek; velhasılı çocuğu ailesinin ve içinde yaşadı̆̆ı cemiyetin lüzumlu ve faide-i bahş bir uzv-1 fa'ali haline getirmekten ibarettir." 30

Böyle bir hedef konulmadan eğitim-öğretim faaliyetinden istenen ve beklenilen bir sonucun alınmasının mümkün olmadığını belirten İslamcılar, bu amaçların gerçekleştirilmesindeki en önemli görevi ise anneye yüklerler. Zira her çocuk bir aile ortamında hayata gözlerini açar, etrafı yani dünyayı orada tanımaya başlar ve bu süreç onun vefatına kadar inişli çıkışlı bir şekilde devam eder. Bu uzun sürecin en önemli saç ayaklarından biri ise ailede çocuğa verilen ilk eğitimdir. ${ }^{31}$ İslamcılara göre çocukların hayata yeni atıldı̆̆ bu zaman diliminde onların kimlik ve kişiliklerinin şekillenmesinde annelerin ciddi bir rolü bulunmaktadır. Anneler, doğduğu andan itibaren çocuğuyla ilgilenen, onun her türlü sıkıntısının giderilmesi için gayret gösteren müstesna şahsiyetlerdir. Nitekim Hz. Peygamber "Cennet anaların ayakları altındadır." ${ }^{32}$ buyurarak İslam'ın kadına ve özellikle anneye verdiği değeri göstermek istemiştir. İslamcılar bu noktada Hz. Peygamberin hadislerinde annelik vasfına bu şekilde vurgu yapmasını çok önemserler ve buradan hareketle kadınların hem bir anne hem de aynı zamanda özellikle bir mürebbiye olduğuna dikkat çekerler. Onlara göre bu süreçte annelerin yapmaları gereken en öncelikli iş, çocuklarına sevgiyle ve şefkatle yaklaşmak ve onlara dünya ve ahiret mutluluğuna ulaşmalarına vesile olacak dinî ve ahlakî bilgileri öğretmektir. ${ }^{33}$

Kadınların annelik ve mürebbiyelik vasfına bu şekilde vurgu yapan İslamcılar, akabinde, dönemin Osmanlı kadınının mevcut durumundan

30 M. Şemseddin, "Talim ve Terbiyede Ebeveynin Vazaifi", Sebilürreşad, 1-8/22-204, (19 Temmuz 1328): 417.

31 Mehmed Sıdkı, “Terbiye-i Etfal ve Birkaç Söz", Beyanü'l-Hak, 5/107, (11 Nisan 1327): 1984. İslamcilar aile ocağında çocukların anneleri yerine yabancı mürebbiyelerin ellerine teslim edilmesini doğru bulmazlar. Onlara göre yabancı mürebbiyelerin dini, ahlakı, milleti, örfü, âdeti, gelenek ve göreneği Müslüman Türk toplumundan tamamen farklıdır. Böylesi bir anlayışa sahip olan söz konusu mürebbiyelerin Müslümanların çocuklarına vereceği hiçbir şey olmadığını belirten İslamcılar, özellikle varlıklı aileleri ve Osmanlı kamuoyunu bu konuda dikkatli olmaya davet ederler. Bununla birlikte İslamcılar, kendisi Müslüman olan ancak çocuk eğitimi konusunda yeteri kadar eğitime ve gerekli donanıma sahip olmayan mürebbiyelerin de kesinlikle aile ortamına alınmamasını ve çocukların onlara emanet edilmemesi gerektiğini ifade ederler. Geniş bilgi için bkz. Safayhi, "Kızlarımıza Ne Okutalım?", 388-389; M. Nuri, “Gençlerimiz Niçin Zaif İ'tikada Düçar Oluyor?”, Hayrü'l-Kelam, 2/27, (8 Mayıs 1330): 211-212; İbnü'l-Emin Mahmud Kemal, "Serbest-i Mezahib", Beyanü'l-Hak, 1/26, (16 Mart 1325): 599-600; Vasif, "Mektup", Strat-l Müstakim, 3/75, (28 Kanun-i Sani 1325): 362.

32 Sünen-i Nesai, Cihad, 6 .

33 Troyskili Ahmed Taceddin, "Validelerimiz...!", Tearüf-i Müslimin, 1/1, (2 Nisan 1326): 11-12; İskilipli Mehmed Atıf, "Medeniyet-i Şer'iye, Terakkiyat-1 Diniye (Ebeveynin Vazâifi ve Terbiye-i Etfal), Beyanü'lHak, 7/171, (30 Temmuz 1328): 3005; Volkan, “Nâci”, Volkan, 1/5, (2 Kanun-i Evvel 1324): 1. 
bahsederek nasıl bir anne olunması gerektiğinin de cevabını bulmaya çalışırlar. Onlara göre "Valide terbiyesi, terbiyenin temeli ve en esaslısıdır." "Beşik sallayan el cihana hükmeder." sözleri öylesine gelişi güzel dile getirilmemiştir. Zira çocuk yetiştirmek dünyanın en zahmetli ve meşakkatli işidir. Bu vazifenin üstesinden gelen bir anne, hayatı boyunca karşılaştığı birçok sıkıntıyı rahatlıkla bertaraf edebilir. Babalar, anneler kadar çocuklarıyla ilgilenemezler. $\mathrm{Bu}$ iş daha çok annenin görevidir. Anne hem aile içinde hem de okulda çocuklarıyla devamlı alakadar olur. Onların akademik başarıları kadar dine, ahlaka ve hayata dair bilgilerinin gelişmesinin de örneği, eve etki edeni yine annedir. Ancak İslamcılar, Osmanlı annelerinin çoğunun kendi çocuklarına neyi, nasıl ve ne kadar öğretecekleri konusunda yeteri kadar donanıma sahip olmadıkları kanaatindedir. Onlara göre bunun en büyük sebebi kadınların evlenmeden önce iyi bir eğitim alamamalarına dayanmaktadır. ${ }^{34}$

Kız çocuklarının evlilikleri boyunca daha iyi bir anne olması için eğitim alıp almamaları gerektiği hakkında görüş belirten İslamcılar arasında bir birliktelik olmadığını belirtmek gerekir. İslamcıların ılımlı kanadı, kızların aile ortamından başlayarak, ilkokul, ortaokul, lise ve üniversiteye kadar mutlaka okutulmasını isterken; muhafazakâr kesimi ise eğitimin önemli olduğunu ancak bir kadının asli görevinin annelik olması hasebiyle kız çocuklarının daha çok lise tahsiline kadar öğrenim görmesi gerektiğini ve akabinde evlendirilip anne olmasının daha uygun bir davranış olduğunu dile getirirler. Birinci görüşü savunan yazarlardan biri olan M. Şemseddin'e göre, Müslüman Türk toplumunun bugün ve gelecekte bilinçli, ne yaptığını bilen, neden bu dünyaya geldiğinin farkında olan ve attığı her adımın sorumluluğunu yüklenecek mesuliyete sahip bireyler olarak yetişebilmesi için pedagojiden anlayan ve anladığını çocuklarına uygulayacak annelere çok ihtiyacı vardır. ${ }^{35} \mathrm{~K}$ ız çocuklarının bilinçli bir anne olabilmesi içinse öğrenim gördüğü okullarda onlara mutlaka anneliğin önemi ve amac1, çocuk doğurma, onu yetiştirme, yavrularına dinî ve ahlakî bilgiler kazandırma, onlara iyi bir rol model olma gibi konularda yeteri kadar malumat verilmelidir. Şemseddin, kızların bu meziyetlerle donatılmasının her anne ve

\footnotetext{
34 Edhem Nejad, "Neden Muallime Yetiştirilmiyor", Sırat-1 Müstakim, 6/155, (10 Ağustos 1327): 390-392; M. Şemseddin, "Tedrisat ve Terbiye-i Ahlakiye", Sebilürreşad, 2-9/33-215, (4 Teşrin-i Evvel 1328): 126-127; "Terbiye-i Nisvan yahut Vazâif-i Nisvan", el-Medaris, 2, (9 Mayıs 1329): 17-20.

35 M.Şemseddin, "Talim ve Terbiyede Mektepler", Sebilürreşad, 1-8/25-207, (9 Ağustos 1328): 478; M. Şemseddin, "Talim ve Terbiye Meselesi", Sebilürreşad, 1-8/20-202, (5 Temmuz 1328): 379; Ayrıca bkz. “Kadınlarımızın Tahsil ve Terbiyesi”, Ceride-i Sufiye, 5/127, (4 Recep 1335): 295-296.
} 
babanın en asli görevlerinden biri olduğunu ifade eder. Devamında ise bir adım daha ileriye giderek söz konusu sorumlulukları ifa etmeyen ya da savsaklayıp geçiştiren ebeveynlerin kendi toplumuna ve kendi insanına karşı ihanet etmekle eşdeğer bir faaliyet içerisinde olduklarını dile getirir. ${ }^{36}$

Samizade Süreyya da kız çocuklarının becerikli ve nitelikli bir anne olması için tahsil görmesi gerektiğini dile getiren yazarlardan biridir. Süreyya; bilgili, kültürlü ve donanımlı çocuklar yetiştirmek için, onların eğitim işiyle uğraşan annelerin de benzer meziyetlere sahip olması gerektiğini söyler. Konuyla ilgili düşüncelerini belirtirken Osmanlı toplumundaki kadınların mevcut durumunu iki şekilde ele alır. Buna göre Osmanlı'da varlıklı ailelerde dünyaya gelen, ufak yaşlardan itibaren iyi bir eğitim alan hatta Avrupalı kadınlardan daha fazla bilgiye ve donanıma sahip olan kızlar/kadınlar bulunmaktadır. Buna karşılık yine Osmanlı' da okuma-yazma bilmeyen, bundan rahatsızlık duymayan yani kendi durumlarına dair herhangi bir endişe taşımayan hatta eğitim-öğretim almayı gereksiz olarak gören kadınlar da bulunmaktadır. Yazara göre böyle bir düşünceye sahip olan kadınların konuya yaklaşımı kendilerine has bir din algısı oluşturmalarından kaynaklanmaktadır. Eğitim-öğretim dâhil ev dışı bütün aktivitelere kapalı olan bu kadınların hayattaki yegâne amacı evlenip kocasına sadık ve itaatkâr bir eş olmaktır. Süreyya, İslam'ın istediği kadın tipinin bundan ibaret olduğunun zannedilmesinden kaynaklanan bu duruma net bir dille karşı çıkmaktadır. Çünkü ilk emri oku olan bu dinde, ilmin önemine işaret eden nice deliller vardır. Ev hayatında sergilenen davranış biçimlerinden, çocukların yetiştirilmesine, çıkabilecek muhtemel problemlere çözüm üretmekten nikâhla yüklenen sınırlılıklara ve sorumluluklara kadar her şeyin temelinde ilim bulunur. Bu açıdan bakıldığında mutlu bir evliliğin kurulup korunabilmesi için dahi erkek kadar kadının da kendisini geliştirmesinin elzem olduğu anlaşılmaktadır. ${ }^{37}$

İkinci görüşü savunan yazarlardan biri olan Musa Kazım'a göre ise kız çocukları eğitim görmelidir; ancak bununla birlikte onların günaha düşmemesi, iffetlerini koruyup dünya ve ahiret saadetini muhafaza etmeleri için gecikmeden bir evlilik yapmaları da gereklidir. ${ }^{38}$ Zira kadınların ilk ve en önemli vazifesi evlenmek, bir aileye sahip olmak, çocuk doğurmak ve dünyaya getirdiği bu çocukların eğitimiyle ilgilenmektir. Bu nedenle

\footnotetext{
Şemseddin, "İctimaî Derdlerimizden İzdivac Mesele-i Mühimmesi”, 344-345.

Samizade Süreyya, "Terbiye-i Nisvan", Tearüf-i Müslimin, 2/25, (25 Teşrin-i Sani 1326): 3-4.

38 Musa Kazım, "Hürriyet-Musavat", Strat-ı Müstakim, 1/2, (12 Ağustos 1324): 22.
} 
kadınların eğitim-öğretim işi ile meşgul olurken şahıslarına atfedilen söz konusu vazifelere yönelik istenmeyen bazı menfi düşünceler içine girmesine ya da o hususlara karşı lakayt bir tavır takınmasına sebep olacaksa, onların lise tahsilinden sonra öğretime devam etmemeleri kendileri için daha hayırlıdır. Yani Kazım'a göre kadınların annelik görevini yerine getirmesi için illa bir üniversite bitirmesine ihtiyaçları yoktur. ${ }^{39}$

Kadınların annelik ve eğitimcilik vasfının bozulmaması için dönemin kamuoyuna bazı uyarılarda da bulunan İslamcılar, özellikle kadınlardaki aşırı Avrupa düşkünlüğüne ve giyimden kuşama kadar Avrupa âdetlerinin taklit edilmesine şiddetle karşı çıkarlar. Onlara göre ister kadın ister erkek olsun insanlar neyi düşünür, neyi beğenir ve neyi elde etmek isterlerse ona uygun bir hareket tarzı geliştirirler ki, İslamcılar açısından asıl sorun burada ortaya çıkmaktadır. Zira tercih edilen bu yeni hayat tarzının hem İslam'ın özüne ve ruhuna hem de Osmanlı toplumunun sosyo-kültürel yapısina muhalif yabancı bir yaşam tarzı olduğunda şüphe yoktur. Böylesi bir durum ise Müslümanların bugün ile gelecekteki yaşam kalitesinin muhafazasını sağlamadaki en etkili unsurlardan biri olan annelerin bu amaçlarından uzaklaşıp motivasyonlarını kaybetmelerine ve asıl işleri olan çocuklarını eğitme konusunda rehavete kapılmalarına neden olmaktadır. Dolayısıyla başta kadınlar olmak üzere, toplumdaki diğer bireylerin bu hususa azami derecede dikkat etmesi gerekir. ${ }^{40}$

İslamcılara göre çocukların eğitiminde özellikle dinî ve ahlakî gelişiminin şekillenmesinde aile terbiyesinin önemi çok büyüktür. Çünkü "Aile terbiyesi, esastır. Esas çürük olursa bilahare ne kadar itina edilirse edilsin yine matlup metanet temin edilemez. Çocuğun alacağı ilk terbiye ister iyi ister fena, ebediyen dimağında payidar olur gider." Bu nedenle İslamcılar bu ilk dönem eğitiminde hem bedenî hem dinî hem de ahlakî bir terbiyenin

39 Musa Kazım, "Hürriyet-Musavat”, Strat-ı Müstakim, 1/3, (28 Ağustos 1324): 36-37. Benzer ifadeler için bkz. "Biz umum-1 İslamlar arzu ederiz ki, kadınlarımızın kalplerinde hissi şefkatten, muhabbeti diniye, vataniye ve zevciyeden başka şeyler yer tutmasın. Onların bütün düşünceleri çocuklarının hüsn-i terbiyesi, dinin ve vatanın muhafazası, zevcelerinin iyi bakılması noktalarına ma'tuf olsun". M. Şükrü, "Kadınlarımız", Beyanü'l-Hak, 4/98, (7 Şubat 1326): 1834. Konuyla ilgili ayrıca bkz. Ferid Vecdi, "Müslüman Kadını", Sirat-ı Müstakim, Müt: Mehmed Akif, 1/3, (28 Ağustos 1324): 42-45; Vecdi, "Müslüman Kadını (Üçüncü Fasıl: Kadın Bedenen ve Ruhen Erkekle Bir Olabilir Mi?)”, 79; Vecdi, “Müslüman Kadını (Dördüncü Faslın Maba'd1)", 104-108.

40 Hoca Fatma Mergube, “İslam Kadınları ve Moda”, Beyanü'l-Hak, 1/9, (17 Teşrin-i Sani 1324): 192-194; Fatma Nezihe, "Tahsil-i Nisvan", Beyanü'l-Hak, 3/75, (16 Ağustos 1326): 1455-1456; Vecdi, "Müslüman Kadını (Dördüncü Faslın Maba'dı)", 103-107. 
birlikte harmanlanması gerektiğinden söz ederler. ${ }^{41}$ Zira aile terbiyesinin çocukların daha sonraki yaşamlarında ne kadar etkili olduğu herkes tarafından kabul edilen bir gerçektir. Buradan hareketle İslamcılar, aile ortamında mutlaka muhabbetin, merhametin ve edebin temele alınması gerektiğini ifade ederler; çünkü bu sayede temelinde söz konusu ahlakî değerlerin yer aldığı ailelerde yetişen çocukların ilgili tavırları içselleştirerek ileriki hayatlarına taşıyabileceklerini ve günü geldiğinde kendi ebeveynlerine karşı aynı sevgi, saygı ve şefkati gösterebileceklerini dile getirirler. ${ }^{42}$

Kişilikli ve ahlaklı birey yetiştirmenin ebeveynlerin en büyük görevi olduğu kanaatinde olan İslamcılara göre Kur'an-1 Kerim'de ve hadis-i şeriflerde anne ve babaların hem kendilerini hem de çocuklarını dünya ve ahiretin musibetlerinden korumak için ellerinden gelen bütün gayreti göstermeleri konusunda ciddi uyarılarda bulunulmaktadır. Bu nedenle ebeveynler, öncelikle evlatlarını helal rızıklarla beslemeli, haramdan daima uzak durmalıdır. Çocuklar konuşmaya ve etrafındaki olaylarla ilgilenmeye başladığı andan itibaren onlara "dinî kavramları öğretmeli, giyinmeyi, kuşanmayı, yemek adabını ve toplum içerisinde nasıl hareket etmesi gerektiğini telkin etmelidir." ${ }^{43}$ Bunun yanında çocuklara Kur'an-1 Kerim okumak, hadis ezberlemek, Hz. Peygamberin, sahabelerin ve bazı İslam büyüklerinin hayatları ile içinde yaşadıkları toplumun diline ait okumayazma becerilerinin geliştirilmesi ve hesap işlerinin öğretilmesi de gerekmektedir. İslamcılara göre bu gibi faaliyetlerle gerek ailede ve gerekse okulda çocukların dinî ve ahlakî konularda bilinçli olmasına yardım edilmelidir. Ayrıca çocukların ibadetleri yapma noktasında hem örnek olunmalı hem de onlar bu konuda teşvik edilmelidir. ${ }^{44}$

Söz konusu eğitim-öğretim işi yapılırken çocukların gelişim özelliklerine dikkat edilmesi gerektiğini belirten İslamcılara göre, her çocuk

41 Şemseddin, “Talim ve Terbiyede Ebeveynin Vazâifi”, 419; Mehmed Fahreddin, “Talim ve Terbiyede Üssü'1Esas 2", Sebilürreşad, 1-8/25-207, (9 Ağustos 1328): 480; Ayrıca bkz. İbnü'1-Emin Ahmed Tevfik, "Esas Terbiye", Beyanü'l-Hak, 1/21, (9 Şubat 1324): 468-470.

42 Süreyya, "Terbiye-i Etfal", 386.

43 Tahirü'l-Mevlevi, “Terbiye ve Ta'limi Etfal”, Beyanü'l-Hak, 2/50, (22 Şubat 1325): 1059-1060.

44 Sıdkı, "Terbiye-i Etfal ve Birkaç Söz", 1985. İslamcılar çocukların aile ocağında nitelikli bir din ve ahlak eğitimi alabilmesi için İslam'ın emrettiği Hz. Peygamberin de bizzat uygulayarak gösterdiği ebeveynin çocuklar, çocukların da anne ve babaları üzerindeki haklarına bihakkın riayet edilmesi gerektiğini söylerler. Her iki tarafın yapması gereken görevlerle ilgili yaklaşık on maddelik bir sıralama yapan İslamcılar, düşüncelerini delillendirmek ve etki gücünü arttırmak maksadıyla Kur'an-1 Kerim'den ayetler, Hz. Peygamberden hadisler, sahabelerin ve bazı İslam büyüklerinin sözlerinden örnekler dile getirirler. Geniş bilgi için bkz. İskilipli Mehmed Atıf, "Terbiye-i Etfal", Beyanü'l-Hak, 4/101, (28 Şubat 1326): 1877-1882; İskilipli Mehmed Atıf, "Medeniyet-i Şer'iye, Terakkiyat-ı Diniye (Evladın Vazâifi), Beyanü'l-Hak, 7/173, (13 Ağustos 1328): 3035-3038; Atıf, "Medeniyet-i Şer'iye, Terakkiyat-ı Diniye (Ebeveynin Vazâifi ve Terbiye-i Etfal)", 3005-3007. 
kendi kabiliyetine ve algılama düzeyine göre yetiştirilmelidir. ${ }^{45}$ Çocuklar yedi yaşına gelince dinin emirleri öğretilmeli ve kademe kademe yaşı ilerledikçe bilgi ve uygulama boyutu birbiri ile paralel bir şekilde devam etmelidir. Yani sadece dinle ilgili kuru bilgi vermek yerine çocuklara aktarılan bilgilerin onlar tarafından severek ve isteyerek yapılması için gerekli çaba gösterilmelidir. ${ }^{46}$ İslamcıların bu yaklaşımı önemlidir; zira aile ortamında çocuklara verilmesi gereken din ve ahlak eğitiminin hem bilgi hem de uygulama boyutunun onların hazırbulunuşluk düzeyine uygun olarak tedrici bir şekilde yerine getirilmesi çocukların hem fizikî hem de ruhî özelliklerinin dikkate alınması anlamina gelmektedir ki, bu günümüz eğitimcilerinin de üzerinde durduğu çok önemli bir meseledir. Görünen o ki, İslamcılar bununla doğru bilgi üzerine inşa edilen bir din ve ahlak eğitiminin içeriğinin çocukların yaşamına yansımasının daha kolay olduğuna inanmaktadırlar.

Aile içerisinde çocukların yaptığı yanlış davranışlar karşısında nasıl bir tepki verileceğinin de belirlenmesini isteyen İslamcılara göre, anne ve babalar çocukların yaramazlıklarına karşı dinî esasları ve dinî kavramları bir tehdit unsuru olarak kullanmamalıdır. Zira çocukları korkutmak için "şeytan gelir, aydede seni döver" gibi tabirler söylenerek bu genç insanların beynine istenmeyen kötü duyguların yerleştirilmesine gerek yoktur. Aslı astarı olmayan hikâyelerin, gerçekle hiçbir bağı olmayan boş hayallerin çocuklara anlatılmaması gerekir. ${ }^{47}$ İslamcılara göre burada yapılması gereken asıl iş çocukların olumlu ve olumsuz davranışlarına karşı tutarlı bir yaklaşım sergilenmesidir. Yani anne ve babasının istediği iyi ve güzel olan davranışları sergileyen çocuklar ödüllendirilmeli; ${ }^{48}$ bunun tam tersi bir davranış içerisinde olan çocuklara ise yaptıkları davranışların yanlış olduğu iyi bir şekilde anlatılmalı, aynı tavrı sergilemeye devam ettikleri takdirde ise o zaman gerekli cezaya çarptırılmalıdır. ${ }^{49}$

İslamcılar aile eğitiminde çocuklara verilen dinî ve ahlakî bilgilerin öğretim süreciyle ilgili birkaç önemli noktaya vurgu yaparlar. Bunlardan ilki çocuklara iyi bir rol model olunması gerektiğidir. Zira çocuklar küçük yaşlarından itibaren her neyi görüp, dinleyip öğrenirlerse onu yapmaya,

\footnotetext{
45 Atıf, "Medeniyet-i Şer' iye, Terakkiyat-1 Diniye (Ebeveynin Vazâifi ve Terbiye-i Etfal)", 3005.

46 İskilipli Mehmed Atıf, "Medeniyet-i Şer'iye, Terakkiyat-1 Diniye”, Beyanü'l-Hak, 7/172, (6 Ağustos 1328): 3022.

47 Atıf, "Medeniyet-i Şer'iye, Terakkiyat-1 Diniye, s.3023; Süreyya, “Terbiye-i Etfal”, 386.

48 Atıf, "Medeniyet-i Şer'iye, Terakkiyat-1 Diniye (Ebeveynin Vazâifi ve Terbiye-i Etfal), 3007; M. Şükrü, “Çocuklarımızı Nasıl Terbiye Edelim!", Beyanü'l-Hak, 5/125, (15 Ağustos 1327): 2267.

49 M. Hilmi, "Terbiye-i Etfal", Maşrık-i İrfan, 1/12, (13 Nisan 1325): 2; el-Mevlevi, "Terbiye ve Ta'limi Etfal", 1060.
} 
beraber yaşadıkları aile bireylerini devamlı taklit etmeye çalışırlar. ${ }^{50}$ Çocuklar bu dönemde âdeta etraflarında görüp duydukları her şeyi zihinlerine kaydederek hafızalarına yerleştirirler. İslamcılara göre işte bu süreçte çocukların algıları dışarıdan gelecek her türlü iyi ya da kötü etkiye açık olduğu için ebeveynlere düşen en önemli görev bu fotoğraflama işinin en az zararla atlatılmasına çalışmak olmalıdır. ${ }^{51}$ Bu nedenle anne, baba ve diğer aile bireylerinin ellerinden geldiği kadar söz ve davranışlarına dikkat ederek çocuklarına iyi bir rol model olmaları gerekmektedir. ${ }^{52}$

İslamcıların üzerinde durduğu ikinci husus çocukların kiminle gezip dolaştığının ve kiminle arkadaşlık ettiğinin takip edilerek kontrol altına alınması gerektiğidir. Çünkü çocukların aile ortamında görüp-duyduğu olumlu davranışların, içinde yaşanılan çevre ile o çevrede bulunan insanlar tarafından da pekiştirilmesi gerekir. İslamcılar bu hususun çocukların sosyalleşmesinde, kendi toplumunun dinî, ahlakî ve insanî değerlerinin benimsenmesinde önemli bir yeri olduğu kanaatindedirler. ${ }^{53}$ Onlara göre gerek aile ve gerekse diğer eğitim süreçlerinin hepsinde bu birey-çevre, çevrebirey etkileşimine dikkat edilmelidir. Bu nedenle eğitimde öncelik hem bireyin hem de o bireyin içerisinde yaşadığı çevrenin dikkate alınarak birlikte planlandığı bir şekilde olmalıdır. ${ }^{54}$ İslamcılar, bu gerçeklerden hareketle, özellikle annelere evlatlarının arkadaşlık yapmak istedikleri bireylerin ve onların ailelerinin dinî ve ahlakî meziyetlerini iyice araştırmalarını, ancak kesin bir kanaate vardıktan sonra çocuklarının bu kişilerle iletişim kurmalarına izin vermeleri gerektiğini tavsiye ederler. ${ }^{55}$

Bir diğger husus ise anne ve babaların çocuklarıyla birlikte zaman geçirmesi, bir birey olarak onlara değer verip karşılıklı bir iletişim dili geliştirmesidir. İslamcılar bu iletişim dilinin çocukların şahsiyetlerinin şekillenmesinde hatırı sayılır bir etkiye sahip olduğunu söylerler. Zira çocukların diğer yetişkinler gibi kendilerine ait duyguları ve bir yaşam alanları vardır. Onlar kendilerini kim sever, kim değer verir ve kim eğlendirirse onu daha çok severken; bunun tam tersi bir davranış içerisinde olan kimselere karşı ise daha mesafelidirler. İslamcılara göre anne ve babalar çocuklarıyla tutarlı bir iletişim ortamı sağlamak, onlara iyi bir eğitim vermek

\footnotetext{
Şükrü, “Çocuklarımızı Nasıl Terbiye Edelim!”, 2266.

Fahreddin, "Talim ve Terbiyede Üssü'l-Esas 2", 479.

52 Şükrü, "Çocuklarımızı Nasıl Terbiye Edelim!”, 2266; Ayrıca bkz. H. Bekir Sıdkı, “Bizde Ahlak, Bizde Terbiye", Hayrü'l-Kelam, 1/23, (10 Nisan 1330): 183-184.

3 Atıf, "Terbiye-i Etfal”, 1879; Süreyya, "Terbiye-i Etfal”, 386.

54 Şemseddin, "Talim ve Terbiyede Ebeveynin Vazaifi", 417.

55 Fatma Sadiye, "Validelere Bir Hitab ve Hanım Kizlara-Nasihat-", Volkan, 1/11, (8 Kanun-i Evvel 1324): 2.
} 
istiyorlarsa buna mutlaka çocukluk döneminden itibaren başlamalıdırlar. ${ }^{56}$ Özellikle çocukluk dönemindeki bu genç insanlara "kavaid-i dîniyeye rağbet ve ahkâm-1 dîniyeye riayet etmenin bir vacibe-i beşeriye" 57 olduğunun kavratılması ve "sözde doğru ile yalanın, itikatta hak ile batılın, ef'alde iyi ile kötünün" 58 arasındaki farkın anlatılması gerekir. Bunlar belki de anne ve babanın çocuğa verebileceği en önemli kazanımların başında gelmelidir. Zira böylece çocuklar ilerleyen yıllarda iyi bir dindar oldukları kadar ahlaklı bir birey de olabilirler.

Çocukların okul hayatında başarılı olabilmesi için mutlaka ailede doğru ve tutarlı bir eğitim alması gerektiğini belirten İslamcılar, bu noktada çocuğa verilecek olan aile terbiyesinin asla onun insanî isteklerini, duygu ve düşüncelerini köreltecek bir yaklaşımla aktarılmaması gerektiğini ifade ederler. Yani devamlı ailesinin yanında oturan, hiç oynamayan, büyükleri karşısında iki büklüm olan, kendisine bir şey sorulduğunda cevap vermekten çekinen bir çocuk asla ve kata iyi bir terbiye almıştır denilemez. Aksine aileler farkında olmadan çocuklarının geleceklerini karartmaktadırlar. Böyle bir yaklaşımla çocuklar kendilerine nasıl güvenecek, nasıl aktif ve girişken bir birey olacaktır. Çocuk ufak yaşlarda etrafta koşup oyun oynasa, yaşının gereği biraz hareketli olsa, hemen kendisini yaramaz bir çocuk olarak nitelemek doğru değildir. İslamcılara göre aileler bu konuda daha dikkatli davranmalı, çocuklarının çekingen ve pısırık bir birey olarak yetişip aynı davranışları okulda sergilemesine asla müsaade etmemelidir. Yani ebeveynler eğitim-öğretim konusundaki en önemli unsurlardan biri olan aileokul, okul-aile etkileşimine ve iş birliğine azami derecede destek olmalıdır. ${ }^{59}$

\section{Sonuç}

İslamcılara göre; iyi bir evlilik için öncelikle dinî kurallara bağlı kalarak tanışma, anlaşma ve nikâh gibi hususlara riayet edilmesi; nikâhta ilk olarak, erkek ve kadın arasında İslam'ın öngördüğü şekilde bir denkliğin sağlanıp sağlanmadığına bakılması gerekmektedir. Zira bir toplumun birlik ve beraberliği, ortak duygu ve düşüncede birleşip kaynaşmaları neticesinde gelişmişlik düzeylerinin artırılmasının yolu aileden geçmektedir. Bu özellikleri sağlayabilen bir aile yapısının oluşturulması Osmanlı toplumunun

\footnotetext{
Süreyya, "Terbiye-i Etfal”, 386.

Şükrü, “Çocuklarımızı Nasıl Terbiye Edelim!”, 2266.

Safayhi, "Kızlarımıza Ne Okutalım?", 388.

59 Hüseyin Hamid, “Bizde Aile ve İbtidai Mektep Muhitleri”, Ceride-i Sufiye, 3/66, (3 Teşrin-i Evvel 1329): 198199.
} 
ileriye dönük teminatı niteliğindedir ki, işte bu sebeple evlenip aile kurmak ve o ailede çocuklara dinî ve ahlakî bilgiler verip onları yetiştirmek İslamcılar tarafından son derece önemli bir beka meselesi olarak görülmektedir.

İstenen bu aile modelinin oluşturulabilmesi için İslamcılar iki noktaya dikkat çekerler. Bunlardan ilki Batı toplumlarının evlilik tarzının taklit edilmemesi; ikincisi ise kadın ve erkeğin yuva içinde ve dışında üzerine düşen görev ve sorumluluklarını yerine getirmeleri gerektiğidir. İslamcılar burada bahsi geçen sorumlulukların çerçevesini çizerken; ev dışı görevleri erkeklerin üzerine yüklemiş, kadının misyonunun ise kocaya itaat etmek, evi çekip çevirmek, çocuk doğurup evlatlarının eğitimiyle ilgilenmek olduğunu belirterek meseleye erkek egemen bir bakış açısıyla yaklaşmışlardır. Bu amaçla kadınlar bu görevleri eksiksiz bir şekilde yerine getirebilecek kadar eğitilmelidir. Kadına verilecek eğitimin temel amacı ise onun bireysel anlamda gelişmesinden ziyade aile içerisinde kendisine yüklenen sorumlulukları en iyi şekilde ifa etmesi amacını taşımaktadır. Çünkü kadın asli görevlerini ihmal ederse Osmanlı aile yapısı bozulur. Aile yapısı bozulan toplum da çökmeye mahkûmdur. Buna göre İslamcılar, toplumun yeniden inşası ve aksamadan devamı için kadının yukarıda sayılan görevleri layıkıyla yapması gerektiğini ifade etmektedirler.

İslamcılar, çocukların dinî ve ahlakî gelişimlerinin doğru ve tutarlı bir şekilde inşasında ailenin rolüne dikkat çekerler. Bu hususta özellikle annelerin çok ciddi bir görev ve sorumluluğu olduğunu belirtirler ve kadınların söz konusu mesuliyeti hakkıyla yerine getirebilmesi için evlenmeden önce iyi bir eğitim alması gerektiğine vurgu yaparlar. Çocukların aile ortamında İslam ahlakına göre yetiştirilmesinde; onlara iyi bir rol model olunması, Kur'an-1 Kerim'in, Hz Peygamber'in, sahabelerin ve bazı İslam büyüklerinin hayatlarının öğretilmesi, dine ve ahlaka dair bilgiler verilirken onların menfi örneklerle korkutulmaması, yaptıkları olumlu ve olumsuz davranışlar karşısında dengeli bir ödül ve ceza sisteminin takip edilmesi, arkadaş seçiminde onlara rehberlik yapılması, ebeveynler ile evlatları arasında doğru ve tutarlı bir iletişimin sağlanabilmesi için çocuğun gelişim özelliklerinin ailesi tarafından iyi bilinmesi ve dikkate alınması gerektiğini ifade ederler.

O halde, bu bilgilerden hareketle, İslamcıların aile içerisinde istedikleri manada bir eğitimle yetiştirmeyi düşündüğü insan modelinin hem dinî değerlerine bağlı hem de bu dinî değerleri hayatına yansıtan kişilikli ve ahlaklı bir birey profili olduğu dile getirilebilir. 


\section{Kaynakça}

“İslam ve Kadınlar: Mazi, Hal ve İstikbal". Hikmet, 14, (8 Temmuz 1326): 5.

"Kadınlarımızın Tahsil ve Terbiyesi". Ceride-i Sufiye, 5/127, (4 Recep 1335): 295-296.

“Terbiye-i Nisvan yahut Vazâif-i Nisvan". el-Medaris, 2, (9 Mayıs 1329): 17-20.

“Teshil-i İzdivac Hakkında”. Sırat-1 Müstakim, 4/88, (29 Nisan 1326): 178.

Atıf, İskilipli Mehmed. “Medeniyet-i Şer'iye, Terakkiyat-ı Diniye (Vazâif-i Zevce). Beyanü'l-

Hak, 7/169, (16 Temmuz 1328): 2971-2972.

Atıf, İskilipli Mehmed. “Medeniyet-i Şer'iye, Terakkiyat-1 Diniye (Ebeveynin Vazâifi ve Terbiye-i Etfal). Beyanü'l-Hak, 7/171, (30 Temmuz 1328): 3005-3007.

“Medeniyet-i Şer'iye, Terakkiyat-1 Diniye (Evladın Vazâifi). Beyanü'l-Hak, 7/173, (13 Ağustos 1328): 3035-3038.

. “Medeniyet-i Şer'iye, Terakkiyat-1 Diniye”. Beyanü'1-Hak, 7/172, (6 Ağustos 1328): 3022.

. “Terbiye-i Etfal”. Beyanü'1-Hak, 4/101, (28 Şubat 1326): 1877-1882.

Aydın, Muhammet Şevki. İslâmcıların Din Eğitimine Bakışı: Mehmed Şemseddin Günaltay Örneği. Ankara: Sarkaç Yayınları, 2013.

Doğan, Recai. “II. Meşrutiyet Döneminde Batıcılık Akımının Din ve Eğitim-Öğretim Görüşlerinin Değerlendirilmesi". Doktora Tezi, Ankara Üniv. Sosyal Bilimler Enstitüsü, Ankara 1996.

Doğan, Recai. İslamcıların Eğitim ve Öğretim Görüşleri. Ankara 1999.

Esad, Mehmed. "İnsanın Mahiyeti ve Vazaif-i Şeri'ye ve İctimaiyesi". Sırat-1 Müstakim, 1/12, (30 Teşrin-i Evvel 1324): 190.

Fahreddin, Mehmed. “Talim ve Terbiyede Üssü'1-Esas 2”. Sebilürreşad, 1-8/25-207, (9 Ağustos 1328): 480.

Fuad, Ali. "Alem-i İslam'da Tesettür-i Nisvan ve Taaddüd-i Zevcat". Ceride-i Sufiye, 1/6-8, (13 Kanun-i Sani 1327): 1.

Göküş, Şeref. “II. Meşrutiyet Dönemi Türkçülük Akımında Eğitim, Din Eğitim ve Öğretimi”. Doktora Tezi, Ankara Üniv. Sosyal Bilimler Enstitüsü, Ankara 2013.

Gündüz, Mustafa. "II. Meşrutiyet Dönemi Türkçü, İslâmcı ve Batıcı Görüşlere Mensup Aydınların Toplumsal Değişme Telakkîleri". Muhafazakâr Düşünce, I/4, (2005): 95-122.

. “100. Yılında II. Meşrutiyet'in Kültürel Mirası”. Milli Eğitim, 184, (2009): 122. . II. Meşrutiyet'in Klasik Paradigmaları. Ankara: Lotus Yayınevi, 2007.

Gürsoy, Ülkü. “II. Meşrutiyet Dönemi Dergileri Üzerine Bir Araştırma”. Doktora Tezi, Gazi Üniv. Sosyal Bilimler Enstitüsü, Ankara 1991.

Hakk1, Bereketzâde İsmail. “Necâib-i Kur'aniye”. Sırat-1 Müstakim, 2/30, (5 Mart 1325): 52-53.

Hamid, Hüseyin. "Bizde Aile ve İbtidai Mektep Muhitleri”. Ceride-i Sufiye, 3/66, (3 Teşrin-i Evvel 1329): 198-199.

Hanioğlu, Şükrü. “Batıcılık”. Tanzimat'tan Cumhuriyet'e Türkiye Ansiklopedisi, C.5, İstanbul: İletişim Yayınları, 1985.

Hilmi, M., “Terbiye-i Etfal”. Maşrık-i İrfan, 1/12, (13 Nisan 1325): 2.

Kara, İsmail. “Tanzimat'tan Cumhuriyet'e İslamcılık Tartışmaları". Tanzimat'tan Cumhuriyet'e Türkiye Ansiklopedisi, C.5, İstanbul: İletişim Yayınları, 1985.

Karakaş, Mehmet. Türk Ulusçuluğunun İnşası. Ankara: Vadi Yayınları, 2000. 
Karasar, Niyazi. Bilimsel İrade Algı Çerçevesi İle Bilimsel Araştırma Yöntemi: Kavramlar-İlkeler-Teknikler, 35. Bsk., Ankara: Nobel Yayın Dağıtım, 2016. . "Hürriyet-Musavat". Sirat-1 Müstakim, 1/2, (12 Ağustos 1324): 22. . "Hürriyet-Musavat". Sırat-1 Müstakim, 1/4, (4 Eylül 1324): 54. "Hürriyet-Musavat". Sırat-1 Müstakim, 1/5, (11 Eylül 1324): 68-70. "Hürriyet-Musavat". Sirat-1 Müstakim, 1/6, (18 Eylül 1324: 94. Hürriyet-Musavat". Sirat-1 Müstakim, 1/7, (25 Eylül 1324): 99-101. “Hürriyet-Musavat. Sırat-1 Müstakim, 1/3, (28 Ağustos 1324): 36-37.

Kemal, İbnü'l-Emin Mahmud. "Serbest-i Mezahib”. Beyanü'l-Hak, 1/26, (16 Mart 1325): 599-600.

Mergube, Hoca Fatma. “İslam Kadınları ve Moda”. Beyanü’l-Hak, 1/9, (17 Teşrin-i Sani 1324): 192-194.

Mevlevi, Tahirü'l. “Terbiye ve Ta'limi Etfal”. Beyanü'l-Hak, 2/50, (22 Şubat 1325): 1059-1060.

Nejad, Edhem. "Neden Muallime Yetiştirilmiyor". Sırat-1 Müstakim, 6/155, (10 Ağustos 1327): 390-392.

Nezihe, Fatma. “Tahsil-i Nisvan”. Beyanü'l-Hak, 3/75, (16 Ağustos 1326): 1455-1456.

Nuri, M., “Gençlerimiz Niçin Zaif I'tikada Düçar Oluyor?". Hayrü'1-Kelam, 2/27, (8 Mayıs 1330): 211-212.

Oba, Ali Engin. Türk Milliyetçiliğinin Doğuşu. Ankara: İmge Yayıncılık, 1995.

Sadiye, Fatma. "Validelere Bir Hitab ve Hanım Kızlara-Nasihat-". Volkan, 1/11, (8 Kanun-i Evvel 1324): 2.

Safayhi, İsmail. “Kızlarımıza Ne Okutalım?”. İslam Dünyası, 1/24, (1329): 388.

Safvet, M., “Şark ve Garp Kadınları”. Beyanü'l-Hak, 3/74, (9 Ağustos 1326): 1437-1440. Sahih-i Buhari, Cenâiz, 92.

Süreyya, Samizade. "Terbiye-i Etfal”, Tearüf-i Müslimin, 1/24, (18 Teşrin-i Sani 1326): 386.

. “Terbiye-i Nisvan”. Tearüf-i Müslimin, 2/25, (25 Teşrin-i Sani 1326): 3-4.

Sarınay, Yusuf. Türk Milliyetçiliğinin Tarihi Gelişimi ve Türk Ocakları. İstanbul: Ötüken Yayınları, 2004.

Sıdkı, H. Bekir. "Bizde Ahlak, Bizde Terbiye”. Hayrü'l-Kelam, 1/23, (10 Nisan 1330): 183-184.

Sıdk1, Mehmed. “Terbiye-i Etfal ve Birkaç Söz”. Beyanü'l-Hak, 5/107, (11 Nisan 1327): 1984.

Sünen-i İbn Mace, Nikah, 9.

Sünen-i Nesai, Cihad, 6 .

Şemseddin, M., "İctimaî Derdlerimizden İzdivac Mesele-i Mühimmesi". Kelime-i Tayyibe, 1/11, (27 Eylül 1328): 341.

. "Nesl-i Atinin Talim ve Terbiyesi". Kelime-i Tayyibe, 1/6, (28 Haziran 1328): 178-179.

. “Talim ve Terbiye Meselesi". Sebilürreşad, 1-8/20-202, (5 Temmuz 1328): 379.

"Talim ve Terbiyede Ebeveynin Vazaifi". Sebilürreşad, 1-8/22-204, (19 Temmuz 1328): 417.

. “Talim ve Terbiyede Mektepler”. Sebilürreşad, 1-8/25-207, (9 Ağustos 1328): 478.

. "Tedrisat ve Terbiye-i Ahlakiye". Sebilürreşad, 2-9/33-215, (4 Teşrin-i Evvel 1328): 126-127. 
Şevki, Ahmed. “Müslümanlarda Aile Hayatı”. Beyanü'l-Hak, 3/71, (19 Temmuz 1326): 1392-1393.

. “Müslümanlarda Aile Hayatı”. Beyanü'l-Hak, 3/72, (26 Temmuz 1326): 14071408.

“Müslümanlarda Aile Hayatı". Beyanü'l-Hak, 3/78, (6 Eylül 1326): 15021504.

“Müslümanlarda Aile Hayatı”. Beyanü'l-Hak, 4/79, (13 Eylül 1326): 15231525.

Şükrü, M., “Çocuklarımızı Nasıl Terbiye Edelim!”. Beyanü'l-Hak, 5/125, (15 Ağustos 1327): 2267.

. “Kadınlarımı". Beyanü'l-Hak, 4/98, (7 Şubat 1326): 1834.

Taceddin, Troyskili Ahmed. "Validelerimiz...!". Tearüf-i Müslimin, 1/1, (2 Nisan 1326): 11-12.

Tevfik, İbnü'l-Emin Ahmed. “Esas Terbiye”. Beyanü'l-Hak, 1/20, (2 Şubat 1324): 453. . "Esas Terbiye”. Beyanü'l-Hak, 1/21, (9 Şubat 1324): 468-470.

Toprak, Zafer. “II. Meşrutiyet'te Fikir Dergileri”. Tanzimat'tan Cumhuriyet'e Türkiye Ansiklopedisi, C.1, İstanbul: İletişim Yayınları, 1985.

Tunaya, Tarık Zafer. İslamcılık Akımı. İstanbul: İBÜY, 2003. . Türkiye' nin Siyasi Hayatında Batılılaşma Hareketleri. İstanbul: İBÜY, 2004.

Varlık, Bülent. “Tanzimat ve Meşrutiyet Dergileri". Tanzimat'tan Cumhuriyet'e Türkiye Ansiklopedisi, C.1, İstanbul: İletişim Yayınları, 1985.

Vasıf. “Mektup”. Sirat-1 Müstakim, 3/75, (28 Kanun-i Sani 1325): 362.

Vecdi, Ferid, "Müslüman Kadını (Beşinci Fasıl: Kadın A'mal-i Hariciyede Erkekle Müşareket Edebilir Mi?)" . Sırat-1 Müstakim, Müt: Mehmed Akif, 1/8, (2 Teşrin-i Evvel 1324): 123-124.

“Müslüman Kadını (Birinci Fasıl: Kadın Nedir?)". Sırat-1 Müstakim, Müt: Mehmed Akif, 1/4, (4 Eylül 1324): 57.

. "Müslüman Kadını (Dördüncü Fasıl)". Sırat-1 Müstakim, Müt: Mehmed Akif, 1/6, (18 Eylül 1324): 90-91.

“Müslüman Kadını (Dördüncü Faslın Maba'dı)". Sırat-1 Müstakim, Müt: Mehmed Akif, 1/7, (25 Eylül 1324): 106-107.

. "Müslüman Kadını (İkinci Fasıl: Kadının Vazife-i Tabiiyesi Nedir?)”. Sırat-1 Müstakim, Müt: Mehmed Akif, 1/4, (4 Eylül 1324): 58-60.

"Müslüman Kadını (Kadının Fıtratında Erkek İşlerine Girişebileceğini Gösterir Bir Şey Var mıdır?)". Sırat-1 Müstakim, Müt: Mehmed Akif, 1/9, (9 Teşrin-i Evvel 1324): 139-141.

. "Müslüman Kadını (Üçüncü Fasıl: Kadın Bedenen ve Ruhen Erkekle Bir Olabilir Mi?)". Sırat-1 Müstakim, Müt: Mehmed Akif, 1/4, (11 Eylül 1324): 76-78.

. “Müslüman Kadını”. Sırat-1 Müstakim, Müt: Mehmed Akif, 1/3, (28 Ağustos 1324): 42-45.

Vefa, Mehmed. “Sefahat ve Kadınlarımız". el-Medaris, 11, (10 Temmuz 1329): 169-170. Volkan, "Nâci". Volkan, 1/5, (2 Kanun-i Evvel 1324): 1.

Yıldırım, Ali \& Şimşek, Hasan. Sosyal Bilimlerde Nitel Araştırma Yöntemleri. 9. Bsk., Ankara: Seçkin Yayınları, 2013. 


\section{Şeref Göküş}

\section{Family and Child Education in the Islamist Viewpoint- Periodicals of the Second Constitutional Period}

Citation/@: Göküş, Şeref, "Family and Child Education in the Islamist Viewpoint- Periodicals of the Second Constitutional Period", Artuklu Akademi 2020/ 7 (1), 99-124.

\section{Extended Abstract}

II. Constitutional Period is one of the most depressing periods of the Ottoman Empire. During this period, many issues that had been accumulated for almost two hundred years started to be loudly expressed in public again and discussed via various media tools. As a consequence of the free environment formed with the declaration of II. Constitutional Monarchy, many different newspapers, and magazines were put into publication one after another. In the periodicals whose numbers can be expressed with hundreds, many different articles were written to discuss on the existing problems on the political, social, economic, cultural, religious, and moral spheres in the Ottoman Empire. When the press and broadcasting life of the period is taken into consideration, it can be seen that the people who are columnists in periodicals consist mostly of intellectuals following the Westernism, Pan-Islamism and Turkism movements. In this process, Westernists through Ijtiha-d and the Ottoman journals; Islamists through Sebilürreşad (Sabił al-Rasha-d), Sırat-ı Müstakim (S $\square$ irat $\square-i$ Mustaqim), Beyanü'lHak (Bayan al-h $\square a q q$ ) and the Islamic World journals; The Turkist through Türk Yurdu (Turkish Land), Islam, Mu'allim (Teacher), Genç Kalemler (Young Pens) and Türk Derneği (Turkish Association) journals tried to find the answer to the question of how should the poor state of the Ottoman State be restored? Of course, the effect of the paradigms of the Westernist, Islamic and Turkist ideas is unignorable since they were gradually processed as from the Tanzimat Reform Era and expanded by their intellectual and cultural characteristics and reached the highest level during II. Constitutional Period.

Westernist, Islamist and Turkist intellectuals tried to create an effective public opinion in their periodicals against by determining the current problems regarding the issues such as education, family, religion, finance, law, morality, and politics that will contribute to shaping the present and the future of the Ottoman society according to them. The intellectuals supporting the relevant opinion reached a consensus on the identification and elimination of the problems. However, it is unfortunately not possible to talk about the same unity in the field of elimination of the related problems such as what works should be carried out in the field and which idea or philosophical basis should be in these works. Accordingly, Westernists claims that the solution of problems related to issues such as education, family, religion, finance, law, morality, and politics can only be achieved through the close recognition and imitation of advanced European societies in many ways. The Islamists, on the other hand, oppose the idea of Westernisation and support that Islam is the only main reference for a 
Muslim, in other words religious and moral teachings shaped by Islam. Turkists, on the other hand, state that as well as spiritual values, national factors that increase unity and solidarity among people should be given importance in solving social problems. This shows that the expectations of the Westernists, Islamists and Turkists to get rid of the crisis of the Ottoman Empire and turn it into a strong state as in the old times are the same. But to achieve this goal, each of them offered different path to follow.

Among the intellectual discussions held during II. Constitutional Period, the views of the Islamists on family and child education are the main focus of this study. In this context, the purpose of this study is to determine how family and child education is handled in the periodicals having an Islamic viewpoint in II. Constitutional Period. To attain this goal, the relevant published literature on the subject was reviewed. Namely, the names of periodicals that reflect the views of the Islamist movement on family and child education were identified as the periodicals such as Beyan'ül-Hak (Bayān al-haqq), Ceride-i İlmiye (Jarīda-i Ilmiyya), Ceride-i Sufiyye (Jarīda-i Șufiyya), Cihan-ı Islam (Jihān-i Islām), el-İslam (al-Islām), elMedaris (al-Madāris), el-Mirsad (al-Mirșād), Hayrü'l-Kelam (Khayr al-Kalām), Hikmet (Hikmah), İrşadü'l-Müslimin (Irshād al-Muslimīn), İslam Dünyasi (Islamic World), Islam and 'Ulum, I'tisam (Itișām), İttihad-ı Islam (Ittihāad-i Islām), Kelime-i Tayyibe (Kalima-i Tayyiba), Maşrık-i Irfan (Mashrīq-i Irfän), Medrese İtikadlari (The Believes of Madāris), Mikyas-ı Şeriat (Miqyās-i Shari'a), Muhibban (Muhibbān), Rehber-i Vatan (Rahbar-i Watan), Sada-i Hak (Sadā-i Haqq), Sebilürreşad (Sabīl al-Rashād), Sirat-ı Müstakim (Șirātt-i Mustaqīm), Tasavvuf (Tașawwufl Mysticism), Tearüf-i Müslimin (Ta'äruf-i Muslimīn) and Volkan (Volcano).

Subsequently, all articles of the periodicals were examined one by one, the articles about family and child education were determined and the relevant information was collected. Considering the content of the articles of the Islamists on the subject, it is understood that two issues are largely emphasized. The first is that marriage should be initiated in accordance with Islamic procedures and the second is that good religious and moral education should be given to the children of this marriage in the family. Based on the findings, this study concentrated on written under two main headings: marriage and starting a family and child education in the family.

As a result of the study, prepared in line with the survey method, the following results were reached. For the Ottoman society to live in unity and solidarity, the Islamists believed that people should comply with religious principles for issues such as meeting stage, making an agreement, and marrying. While marrying, they should check whether there is an equivalence ( $\left.k a f a^{\prime} a h\right)$ between the prospective groom and the prospective wife in accordance with Islam. Stating that the start establishment of such a family structure is the future guarantee of the Ottoman society, the Islamists consider marrying and starting a family and giving children religious and moral education in the family as a vitally important issue. However, the Islamists draw attention to two points in order to realize this family model. The first is not to imitate the family form of Western societies; the second is that men and women should fulfill their duties and responsibilities, both inside and outside the home. By handling the issue from a male-oriented 
perspective, the Islamists have placed duties on men outside the home and the main task of women is to obey the husband, to keep the house, to give birth to children, and to take care of their education.

The Islamists state that mothers have a very crucial duty and responsibility to provide proper and consistent religious and moral education in the family. They also highlight that mothers should receive a decent education before marriage in order to fulfill the responsibilities imposed on them. According to the Islamists, the issues such as being a good role model, considering the children's personality development, following a balanced reward-punishment system, developing an appropriate and consistent communication language, providing basic information about religion and morality, and helping them in choosing friends should be respected while providing a qualified education to the children in the family. Based on all these explanations; the ideal human model that the Islamists intend to train can be stated as a personality and moral individual profile that both depend on religious values and reflects these religious values on life. 